\title{
Radiological significance of marble used for construction of dwellings in Bangladesh
}

\author{
S. GHOSE $^{1 *}$, Kh. ASADUZZAMAN ${ }^{1}$, N. ZAMAN $^{2}$
}

(Manuscript received 6 June 2011, accepted 21 November 2011)

ABSTRACT The natural $\gamma$-radiation in samples of a variety of marbles imported into Bangladesh for use in building construction was measured, employing $\gamma$-ray spectrometry with a HPGe detector. From the measured $\gamma$-ray spectra, activity concentrations were determined for ${ }^{226} \mathrm{Ra}\left(29.31 \pm 2.06\right.$ to $\left.46.99 \pm 2.97 \mathrm{~Bq} \cdot \mathrm{kg}^{-1}\right),{ }^{232} \mathrm{Th}(42.91 \pm 2.53$ to $\left.62.92 \pm 3.37 \mathrm{~Bq} \cdot \mathrm{kg}^{-1}\right)$ and ${ }^{40} \mathrm{~K}\left(824.42 \pm 15.42\right.$ to $\left.1071.58 \pm 20.14 \mathrm{~Bq} \cdot \mathrm{kg}^{-1}\right)$. The measured activity concentrations for these natural radionuclides were compared with the reported data of other countries and with the world average activity of soil. The radium equivalent activity $\left(\mathrm{Ra}_{\mathrm{eq}}\right)$, the hazard indices, the gamma activity concentration index, the indoor absorbed dose rate and the corresponding annual effective dose were estimated for the potential radiological hazard of the marble. The $\mathbf{R a}_{\mathrm{eq}}$ values of all marble samples are lower than the limit of $370 \mathrm{~Bq} \cdot \mathrm{kg}^{-1}$, equivalent to a dose of $1.5 \mathrm{mSv}^{-1} \mathrm{y}^{-1}$. The average values of the external and internal hazard indices are less than unity. The average indoor absorbed dose rate $\left(121.25 \mathrm{nGy}^{-1}\right)$ is higher than the population-weighted average of $84 \mathrm{nGy}^{-1} \mathrm{~h}^{-1}$, whereas the corresponding annual dose limit falls within an average value of $0.60 \mathrm{mSv}$, which is an order of magnitude below the limit specified for building materials in the literature. The present results indicate that using marble in building construction in Bangladesh does not pose any significant radiological hazard.

Keywords: Marble / gamma spectrometry / radioactivity / radiation exposure / Bangladesh

RÉSUMÉ Les radiations $\gamma$ naturelles dans des échantillons de différents marbres importés au Bangladesh pour la construction de bâtiments ont été mesurées en utilisant un spectromètre $\gamma$ avec un détecteur HPGe. À partir des spectres $\gamma$ mesurés, les concentrations ont été déterminées pour le ${ }^{226} \mathrm{Ra}($ de $29,31 \pm 2,06$ à $46,99 \pm$ $\left.2,97 \mathrm{~Bq} \cdot \mathrm{kg}^{-1}\right), \mathrm{le}^{232} \mathrm{Th}\left(\mathrm{de} 42,91 \pm 2,53\right.$ à $\left.62,92 \pm 3,37 \mathrm{~Bq} \cdot \mathrm{kg}^{-1}\right)$ et le ${ }^{40} \mathrm{~K}(\mathrm{de} 824,42 \pm$ 15,42 à $\left.1071,58 \pm 20,14 \mathrm{~Bq} \cdot \mathrm{kg}^{-1}\right)$. Les activités mesurées de ces radionucléides naturels ont été comparées à celles d'autres pays ainsi qu'avec l'activité moyenne mondiale des sols. L'activité équivalente en radium $\left(\mathrm{Ra}_{\mathrm{eq}}\right)$, les indices de risque, l'indice d'activité $\gamma$, le débit de dose absorbé en intérieur et la dose effective annuelle correspondante ont été calculés pour estimer le risque radiologique potentiel du marbre. Les valeurs de $\mathbf{R a}_{\text {eq }}$ de tous les échantillons de marbre sont inférieures à la limite $370 \mathrm{~Bq} \cdot \mathrm{kg}^{-1}$, équivalent à une dose de $1,5 \mathrm{mSv} \cdot \mathrm{y}^{-1}$. Les valeurs moyennes des indices de risque externe et interne sont inférieures à l'unité. Le débit de dose absorbé moyen en intérieur $\left(121,25 \mathrm{nGy} \cdot \mathrm{h}^{-1}\right)$ est supérieur à la valeur moyenne à la population qui est de $84 \mathrm{nGy} . \mathrm{h}^{-1}$, alors que la limite de dose annuelle correspondante se trouve autour d'une valeur moyenne de $0,60 \mathrm{mSv}$, ce qui est un ordre de magnitude inférieur à la valeur limite spécifiée pour les matériaux de construction dans la littérature. Ces résultats montrent que l'utilisation de marbre dans la construction de bâtiments au Bangladesh ne présente pas de risque radiologique significatif.

\footnotetext{
Bangladesh Atomic Energy Commission, GPO Box 158, Dhaka, Bangladesh

Bangladesh University of Engineering \& Technology, Dhaka, Bangladesh.

Present Address: Nuclear Safety \& Radiation Control Division, 4 Kazi Nauru Islam Avenue, Ramna, Dhaka.
} 


\section{Introduction}

Natural radioactivity is common in rocks, soils, and water and building materials. The knowledge of radioactivity present in building materials enables one to assess any possibility of radiological hazard to humans by the use of such materials, as most of the residents spend about $80 \%$ of their time indoors. This knowledge is essential for the development of standards and guidelines for the use and management of these materials. The naturally occurring radionuclides present in building materials including soil are ${ }^{238} \mathrm{U},{ }^{232} \mathrm{Th},{ }^{226} \mathrm{Ra}$ and ${ }^{40} \mathrm{~K}$, which are the main sources of radiation of building materials (Khan et al., 1998; Nageswara, 1989). There has been increased interest from the public at large in knowing information about the presence of naturally occurring radionuclides such as $\mathrm{U}, \mathrm{Th}$, $\mathrm{K}$ and their decay products in construction materials such as bricks, marbles, etc. Like other construction materials, the natural radioactivity in marble may give rise to external and internal exposure. The external radiation exposure is caused by gamma radiation from primordial nuclides; however, the internal radiation exposure, mainly affecting the respiratory tract, is due to inhalation of the radioactive inert gas radon $\left({ }^{222} \mathrm{Rn}\right)$ and its short-lived progeny, which are exhaled from construction materials into rooms in air (Mustonen, 1984; Iqbal et al., 2000).

In geology, any metamorphic rock composed of crystalline aggregate of calcite/dolomite is termed marble, and is found to occur on the earth's surface. Due to its polished surface and availability in a variety of attractive colors, it is widely used as building/construction material. The colors of the marble depend upon the mineral composition and also the metamorphism. It is a well-known fact that the metamorphic rocks such as marbles are composed of felsic minerals (quartz and feldspar) and calcite $\left(\mathrm{CaCO}_{3}\right)$ in major amounts, and mafic minerals (magnetite, hematite, iron oxides) in minor amounts (Ramasamy et al., 2005). Felsic minerals are leucocratic (light-colored) and mafic minerals are malanocratic (dark-colored) in nature.

Keeping in mind the increasing trend worldwide of the use of marbles as a building/construction material, a study was undertaken to assess the radiological risks associated with the marbles being used in the houses. The objective of this work is to investigate to what extent the use of marbles in Bangladeshi dwellings gives rise to radiological hazards. Due to the health risks associated with exposure to indoor radiation, many governmental and international organizations such as the International Commission on Radiological Protection (ICRP), the World Health Organization (WHO), UNSCEAR, etc. have adopted strong measures aimed at minimizing such exposure. In many countries limits have been set on the concentration of radionuclides in various building materials and the use of materials with high levels of activity has been banned. A significant amount of 
marble (as construction raw material) is imported from different countries (mainly from India, Italy and Pakistan) into Bangladesh. Presently, there are no standards or guidelines prescribing the acceptable levels of radioactivity in marble or other building materials in the country as in some industrialized countries (Steger et al., 1992). The specific aim of the present study is to establish broad baseline data on radiation exposure of natural series nuclides in imported marble as well as assessing the potential radiological hazards to humans. The results for the measured activities, the radium equivalent activity concentrations, the internal and external hazard indices, the indoor gamma dose rate and the corresponding annual effective dose associated with the usage of different kinds of marble used in Bangladeshi dwellings are reported in this paper. The results obtained in the present study were compared with the findings of some other studies for marble.

\section{Materials and methods}

\subsection{Sample collection and preparation}

A total of 57 marble samples of nineteen varieties (depending on type and origin) were collected from marble dealers in and around Dhaka city for the measurement of radioactivity concentrations. All the samples were brought to the laboratory and the samples were properly cataloged, washed and dried for complete removal of moisture. Afterwards, each marble sample was crushed to a fine powder with a particle size less than $1 \mathrm{~mm}$. The samples were packed and sealed in radonimpermeable airtight cylindrical plastic containers $(7.5 \mathrm{~cm}$ height and $4 \mathrm{~cm}$ diameter). All the samples were then stored for $4-5$ weeks before counting so as to ensure ${ }^{226} \mathrm{Ra}$ and its short-lived progeny reached secular equilibrium (Amrani and Tahtat, 2001; Khan and Khan, 2001; Kumar et al., 1999, 2003).

\subsection{Gamma-ray detection system}

The concentrations of ${ }^{226} \mathrm{Ra},{ }^{232} \mathrm{Th}$ and ${ }^{40} \mathrm{~K}$ in the marble samples were determined with a high-resolution HPGe gamma ray spectrometry system. The system was equipped with a coaxial p-type HPGe detector with an active volume of $121 \mathrm{~cm}^{3}$ manufactured by Canberra. The HPGe detector has a relative efficiency of $40 \%$, and an energy resolution of $1.8 \mathrm{keV}$ at $1332.5 \mathrm{keV}$. Spectral data from the detector was accumulated on a PCA and analyzed using Genie-2000 software from Canberra. The detector is shielded by a lead cylindrical shield of $94 \mathrm{~mm}$ thickness and $406 \mathrm{~mm}$ height with an inner lining of $16 \mathrm{~mm}$-thick steel plate, which provided an efficient suppression of the background gamma radiation present at the laboratory site. Background measurements were taken and subtracted in order to obtain net counts for the sample. The energy-dependent detection photopeak 
efficiency was determined using a calibrated ${ }^{152} \mathrm{Eu}$ gamma reference source. Considering an uncertainty of $2 \%$ in the source activity, the mean uncertainty in the calculated efficiency is estimated to be about 2 to $3 \%$. The activity concentrations were calculated based on the weighted mean value of their respective decay products in equilibrium. The main contributors to radiological significance are the members of the ${ }^{238} \mathrm{U}$ and ${ }^{232} \mathrm{Th}$ decay series and ${ }^{40} \mathrm{~K}$. Therefore, the emphasis was on the determination of specific activity of ${ }^{226} \mathrm{Ra},{ }^{232} \mathrm{Th}$ and ${ }^{40} \mathrm{~K}$. The content of ${ }^{40} \mathrm{~K}$ was determined by measuring its single peak, $1460.8 \mathrm{keV}$ (10.7). Assuming secular equilibrium in the uranium and thorium decay series, the ${ }^{226} \mathrm{Ra}$ and ${ }^{232} \mathrm{Th}$ activities were determined indirectly via the activities of their daughter products. The choice of the reference nuclides was made so that the related peaks were sufficiently discriminated and intense. Based on such criteria, the content of ${ }^{226} \mathrm{Ra}$ was measured using $\gamma$-energy of $295.21 \mathrm{keV}(18.15){ }^{214} \mathrm{~Pb}$, $351.92 \mathrm{keV}(35.10){ }^{214} \mathrm{~Pb}, 609.32 \mathrm{keV}$ (44.60) ${ }^{214} \mathrm{Bi}, 1120.29 \mathrm{keV}$ (14.70) and $1764 \mathrm{keV}(15.10){ }^{214} \mathrm{Bi}$. The content of ${ }^{232} \mathrm{Th}$ was determined using $238.63 \mathrm{keV}(43.50){ }^{212} \mathrm{~Pb}, 338 \mathrm{keV}(11.26){ }^{228} \mathrm{Ac}, 583.19 \mathrm{keV}(30.70){ }^{208} \mathrm{Tl}$, $911.16 \mathrm{keV}(26.60){ }^{228} \mathrm{Ac}, 968.97 \mathrm{keV}(16.23){ }^{228} \mathrm{Ac}$ and $2614 \mathrm{keV}(35.60){ }^{208} \mathrm{Tl}$. Each sample was counted twice before an average was taken.

\section{Results and discussion}

The laboratory code and local brand name of the marble samples are shown in Table I. Table II provides the results for concentrations of ${ }^{226} \mathrm{Ra},{ }^{232} \mathrm{Th}$ and ${ }^{40} \mathrm{~K}$, together with the standard deviation (SD), in various marble samples used in Bangladesh. The specific radioactivity of ${ }^{226} \mathrm{Ra},{ }^{232} \mathrm{Th}$ and ${ }^{40} \mathrm{~K}$ in the analyzed marble samples ranges from $29.31 \pm 2.06$ to $46.99 \pm 2.97 \mathrm{~Bq} \cdot \mathrm{kg}^{-1}$ with an average of $36.24 \pm 1.91 \mathrm{~Bq} \cdot \mathrm{kg}^{-1}$ for ${ }^{226} \mathrm{Ra}, 42.91 \pm 2.53$ to $62.92 \pm 3.37 \mathrm{~Bq} \cdot \mathrm{kg}^{-1}$ with an average of $52.36 \pm 2.33 \mathrm{~Bq} \cdot \mathrm{kg}^{-1}$ for ${ }^{232} \mathrm{Th}$, and $824.42 \pm 15.42$ to $1071.58 \pm$ $20.14 \mathrm{~Bq} \cdot \mathrm{kg}^{-1}$ with an average of $922.10 \pm 13.35 \mathrm{~Bq} \cdot \mathrm{kg}^{-1}$ for ${ }^{40} \mathrm{~K}$, respectively.

The weighted averages for the detected radionuclide are given at the end of the table along with the standard deviation. As can be seen from Table II, the average value of ${ }^{226} \mathrm{Ra}$ and ${ }^{232} \mathrm{Th}$ in marble in this study is in the range of the corresponding typical world value, which is $50 \mathrm{~Bq} \cdot \mathrm{kg}^{-1}$, whereas the average value of ${ }^{40} \mathrm{~K}$ in this study is higher than the corresponding typical world value, which is 500 Bq. $\mathrm{kg}^{-1}$ (UNSCEAR, 1993).

\subsection{Radium equivalent activity $\left(R a_{e q}\right)$}

The distribution of ${ }^{226} \mathrm{Ra},{ }^{232} \mathrm{Th}$, and ${ }^{40} \mathrm{~K}$ in different types of marble samples is not uniform, so that, in comparing the radioactivity of materials that contain Ra, 
TABLE I

Laboratory code and local brand name of marble samples used for the construction of dwellings in Bangladesh.

\begin{tabular}{ll}
\hline $\begin{array}{l}\text { Sample } \\
\text { Lab. Code }\end{array}$ & Local brand name \\
\hline MBIT-1 & Green marble \\
\hline MBIT-2 & Stone coffee marble \\
\hline MBIT-3 & P.S. gold marble \\
\hline MBIT-4 & Cararra pearl marble \\
\hline MBIT-5 & Cararra white marble \\
\hline MBIT-6 & Black marble \\
\hline MBIT-7 & Perlatino cicily marble \\
\hline MBIT-8 & Bardi galio marble \\
\hline MBIND-9 & Baswara marble \\
\hline MBIND-10 & Stone cota marble \\
\hline MBIND-11 & Black marble \\
\hline MBIND-12 & Green marble \\
\hline MBIND-13 & Onax marble \\
\hline MBIND-14 & Rajnagar marble \\
\hline MBIND-15 & Pink marble \\
\hline MBPAK-16 & Onax marble \\
\hline MBPAK-17 & Zebra black marble \\
\hline MBGRE-18 & Silet marble \\
\hline MBPORT-19 & Razulo marble \\
\hline
\end{tabular}

Th and $\mathrm{K}$ a common index termed radium equivalent activity (Beretka and Mathew, 1985; Malanca et al., 1993) is required to obtain the total activity and is also used to assess the radiological hazard of the building materials used. Radium equivalent activity $\left(\mathrm{Ra}_{\mathrm{eq}}\right)$ is defined as the weighted sum of the activities of the above three radionuclides based on the estimation that $370 \mathrm{~Bq} \cdot \mathrm{kg}^{-1}$ of ${ }^{226} \mathrm{Ra}, 259$ Bq. $\mathrm{kg}^{-1}$ of ${ }^{232} \mathrm{Th}$ or $4810 \mathrm{~Bq} \cdot \mathrm{kg}^{-1}$ of ${ }^{40} \mathrm{~K}$ produce the same $\gamma$-ray dose (Stranden, 1976; Krisiuk et al., 1971; UNSCEAR, 1982);

$$
\mathrm{Ra}_{\mathrm{eq}}=370\left(\frac{\mathrm{A}_{\mathrm{Ra}}}{370}+\frac{\mathrm{A}_{\mathrm{Th}}}{259}\right)+\frac{\mathrm{A}_{\mathrm{K}}}{4810}
$$

where $A_{\mathrm{Ra}}, \mathrm{A}_{\mathrm{Th}}$ and $\mathrm{A}_{\mathrm{K}}$ are the activity concentrations of ${ }^{226} \mathrm{Ra},{ }^{232} \mathrm{Th}$ and ${ }^{40} \mathrm{~K}$ in Bq. $\mathrm{kg}^{-1}$, respectively. The calculated radium equivalent $\left(\mathrm{Ra}_{\mathrm{eq}}\right)$ activities of marble samples are given in Table II. The values obtained were found to range from 165.05 to $214.27 \mathrm{~Bq} \cdot \mathrm{kg}^{-1}$ with an average of $181.98 \mathrm{~Bq} \cdot \mathrm{kg}^{-1}$. For the safe utilization of materials, the maximum value of $\mathrm{Ra}_{\mathrm{eq}}$ must be less than $370 \mathrm{~Bq} \cdot \mathrm{kg}^{-1}$ 
TABLE II

Activity concentrations (Bq.kg ${ }^{-1}$ ) of ${ }^{226} \mathrm{Ra},{ }^{232} \mathrm{Th}$ and ${ }^{40} \mathrm{~K}$ in marble samples used in Bangladesh.

\begin{tabular}{|c|c|c|c|c|}
\hline \multirow{2}{*}{$\begin{array}{l}\text { Sample } \\
\text { Lab. code }\end{array}$} & \multicolumn{3}{|c|}{ Radioactivity concentration $\left(\mathrm{Bq} \cdot \mathrm{kg}^{-\mathbf{1}}\right)$} & \multirow[t]{2}{*}{$\mathrm{Ra}_{\mathrm{eq}}\left(\mathrm{Bq} \cdot \mathrm{kg}^{-1}\right)$} \\
\hline & ${ }^{226} \mathrm{Ra}$ & ${ }^{232} \mathrm{Th}$ & ${ }^{40} K$ & \\
\hline MBIT-1 & $34.61 \pm 1.81$ & $49.33 \pm 2.18$ & $913.67 \pm 12.06$ & 175.36 \\
\hline MBIT-2 & $46.48 \pm 2.95$ & $60.68 \pm 3.56$ & $1054.38 \pm 20.4$ & 214.27 \\
\hline MBIT-3 & $38.25 \pm 2.7$ & $62.92 \pm 3.37$ & $1071.58 \pm 20.14$ & 210.56 \\
\hline MBIT-4 & $33.08 \pm 1.68$ & $50.36 \pm 2.19$ & $898.19 \pm 12.12$ & 174.11 \\
\hline MBIT-5 & $29.31 \pm 2.06$ & $51.70 \pm 2.7$ & $824.42 \pm 15.42$ & 166.58 \\
\hline MBIT-6 & $36.87 \pm 1.66$ & $53.26 \pm 2.19$ & $915.08 \pm 12.21$ & 183.35 \\
\hline MBIT-7 & $35.89 \pm 1.7$ & $55.62 \pm 2.13$ & $902.58 \pm 11.95$ & 184.78 \\
\hline MBIT-8 & $33.99 \pm 1.6$ & $54.74 \pm 2.17$ & $912.65 \pm 12.09$ & 182.39 \\
\hline MBIND-9 & $33.86 \pm 1.72$ & $50.25 \pm 2.18$ & $917.32 \pm 12.02$ & 176.21 \\
\hline MBIND-10 & $36.31 \pm 1.68$ & $52.57 \pm 2.23$ & $933.41 \pm 12.23$ & 183.21 \\
\hline MBIND-11 & $34.62 \pm 1.8$ & $52.03 \pm 2.16$ & $918.40 \pm 12.03$ & 179.59 \\
\hline MBIND-12 & $35.64 \pm 1.72$ & $54.00 \pm 2.05$ & $888.93 \pm 12.09$ & 181.16 \\
\hline MBIND-13 & $33.72 \pm 2.23$ & $42.91 \pm 2.53$ & $910.42 \pm 17.23$ & 165.05 \\
\hline MBIND-14 & $33.99 \pm 1.61$ & $52.61 \pm 2.05$ & $912.92 \pm 11.22$ & 179.37 \\
\hline MBIND-15 & $34.51 \pm 1.57$ & $55.54 \pm 2.14$ & $921.71 \pm 12.16$ & 184.75 \\
\hline МВРАК-16 & $46.99 \pm 2.97$ & $49.19 \pm 2.11$ & $885.14 \pm 12.39$ & 185.35 \\
\hline MBPAK-17 & $40.3 \pm 1.72$ & $50.62 \pm 2.1$ & $917.45 \pm 11.93$ & 183.19 \\
\hline MBGRE-18 & $36.22 \pm 1.6$ & $49.22 \pm 2.22$ & $905.29 \pm 12.13$ & 176.17 \\
\hline MBPORT-19 & $33.97 \pm 1.61$ & $47.38 \pm 2.12$ & $916.37 \pm 11.91$ & 172.15 \\
\hline Maximum & $46.99 \pm 2.97$ & $62.92 \pm 3.37$ & $1071.58 \pm 20.14$ & 214.27 \\
\hline Minimum & $29.31 \pm 2.06$ & $42.91 \pm 2.53$ & $824.42 \pm 15.42$ & 165.05 \\
\hline Average & $36.24 \pm 4.32$ & $52.36 \pm 4.51$ & $922.1 \pm 54.64$ & $181.98 \pm 12.24$ \\
\hline
\end{tabular}

(Beretka and Mathew, 1985; NEA/OECD, 1979; Malanca et al., 1993; Stranden, 1976; Krisiuk et al., 1971). Based on this criterion, it is observed that the $\mathrm{Ra}_{\mathrm{eq}}$ values for all the studied samples are lower than the recommended value except one sample (MBPAK-16), which exceeds the world average limit. Thus, these samples are within the recommended safety limit when used as building materials.

A comparative study of the average activity concentrations of ${ }^{226} \mathrm{Ra},{ }^{232} \mathrm{Th}$ and ${ }^{40} \mathrm{~K}$ and $\mathrm{Ra}_{\mathrm{eq}}$ concentrations with similar data from some other countries are presented in Table III. It is apparent that the $\mathrm{Ra}_{\mathrm{eq}}$ of marbles originating from different regions shows considerable variation, which is likely related to the 
TABLE III

Comparison of the average activity concentrations and radium equivalent activities $\left(\mathbf{R a}_{\mathrm{eq}}\right)$ of marble samples (present study) with those obtained in other published data.

\begin{tabular}{|c|c|c|c|c|c|}
\hline \multirow[t]{2}{*}{ Country } & \multicolumn{3}{|c|}{ Radioactivity concentration $\left(\mathrm{Bq} \cdot \mathrm{kg}^{-1}\right)$} & \multirow{2}{*}{$\underset{\left(B \mathbf{B q} \cdot \mathbf{k g}^{-1}\right)}{\mathbf{R a}_{\mathbf{e q}}}$} & \multirow[t]{2}{*}{ References } \\
\hline & ${ }^{226} \mathrm{Ra}$ & ${ }^{232} \mathrm{Th}$ & ${ }^{40} \mathrm{~K}$ & & \\
\hline Bangladesh & $36.24 \pm 1.91$ & $52.36 \pm 2.33$ & $922.1 \pm 13.35$ & 181.98 & Present work \\
\hline Pakistan & 7.85 & 2.74 & 25.80 & $13.69 \pm 7.55$ & Aslam et al. \\
\hline Pakistan & $4-63$ & $9-40$ & $7-105$ & $25-99$ & Iqbal et al. \\
\hline India & $7.79^{\mathrm{a}}$ & 12.42 & 241.98 & 44.20 & Ramasamy et al. \\
\hline Turkey & $\begin{array}{l}0.6 \pm 0.1- \\
27.3 \pm 1.3\end{array}$ & $\begin{array}{l}1.2 \pm 0.1- \\
11.8 \pm 1.0\end{array}$ & $\begin{array}{c}2.9 \pm 0.1- \\
366.7 \pm 9.3\end{array}$ & - & Turhan et al. \\
\hline Egypt - Qena city & $205 \pm 83$ & - & $870 \pm 390$ & $436 \pm 199$ & Nour Khalifa Ahmed \\
\hline Egypt & - & - & - & $\begin{array}{l}5.46 \pm 0.16- \\
150.52 \pm 4.52\end{array}$ & Walley et al. \\
\hline Algeria & - & - & - & 73 to 78 & Amrani and Tahtat \\
\hline Sicily & - & - & - & $128-203$ & Rizzo et al. \\
\hline World average & 50 & 50 & 500 & 370 & UNSCEAR \\
\hline
\end{tabular}

mineral content and geological origin of the marble. This fact is important from the point of view of selecting suitable marbles for use in dwelling construction and decorative material, especially those which have large variations in their activities. The comparison also indicates that the average values of $\mathrm{Ra}_{\mathrm{eq}}$ obtained in the present work were found to be higher compared with those reported from India (Ramasamy et al., 2005); Pakistan (Iqbal et al., 2000; Aslam et al., 2002); Egypt (Walley El-Dine et al., 2001) and Algeria (Amrani and Tahtat, 2001), but lower than the values of Egypt - Qena city (Nour Khalifa Ahmed, 2005).

\subsection{External hazard index $\left(H_{e x}\right)$ and internal hazard index $\left(H_{i n}\right)$}

The external hazard index $\left(\mathrm{H}_{\mathrm{ex}}\right)$ is another radiation hazard index defined by Beretka and Mathew (1985) to evaluate the radiation dose rate due to the external exposure to $\gamma$-radiation from the natural radionuclides in the construction building materials of dwellings. This index value must be less than unity to ensure that the radiation hazard is insignificant, i.e. the radiation exposure due to the radioactivity from construction materials is limited to $1.5 \mathrm{mSv} \cdot \mathrm{y}^{-1}$ based on the formula:

$$
\mathrm{H}_{\mathrm{ex}}=\frac{\mathrm{A}_{\mathrm{Ra}}}{370}+\frac{\mathrm{A}_{\mathrm{Th}}}{259}+\frac{\mathrm{A}_{\mathrm{K}}}{4810}
$$




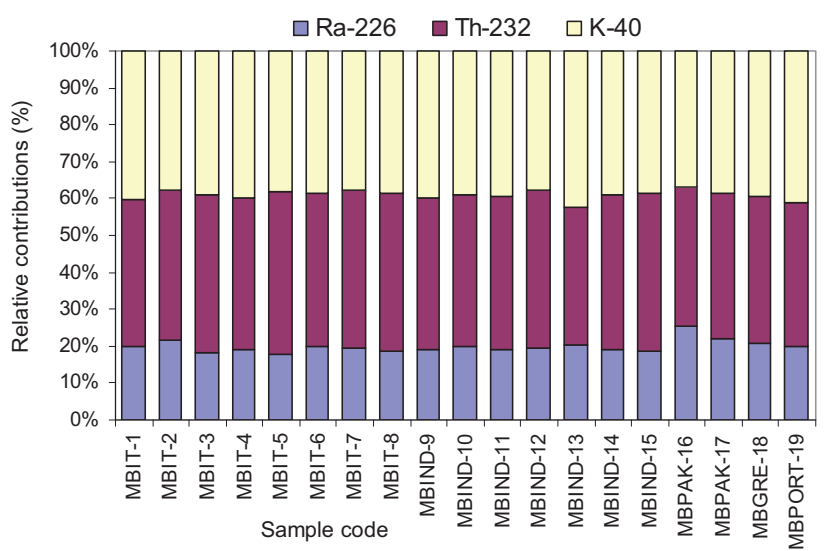

Figure 1 - Relative contributions to the $R a_{e q}$ and Hex rate owing to ${ }^{226} \mathrm{Ra},{ }^{232} \mathrm{Th}$ and ${ }^{40} \mathrm{~K}$ for the marble samples.

where $A_{R a}, A_{T h}$ and $A_{K}$ represent the activity concentration $\left(B q \cdot \mathrm{kg}^{-1}\right.$ ) of ${ }^{226} \mathrm{Ra}$, ${ }^{232} \mathrm{Th}$ and ${ }^{40} \mathrm{~K}$, respectively. The calculated values of $\mathrm{H}_{\mathrm{ex}}$ for the marble samples analyzed in this work range from 0.45 to 0.58 with an average of 0.49 , as shown in Table IV, values which are indeed less than unity. The relative contributions of ${ }^{226} \mathrm{Ra},{ }^{232} \mathrm{Th}$ and ${ }^{40} \mathrm{~K}$ contents to the $\mathrm{Ra}_{\mathrm{eq}}$ and the $\mathrm{H}_{\mathrm{ex}}$ for all marble samples are shown in Figure 1. As can be seen from Figure 1, the average relative contribution by individual components of natural radioactivity is $20 \%$ from ${ }^{226} \mathrm{Ra}$, $41 \%$ from ${ }^{232}$ Th and $39 \%$ from ${ }^{40} \mathrm{~K}$.

In addition to the external hazard, radon and its short-lived daughter products are also hazardous to the respiratory organs. Internal exposure to radon and its daughter products is quantified by the internal hazard index $\left(\mathrm{H}_{\mathrm{in}}\right)$, which is calculated from the following relationship (Beretka and Mathew, 1985):

$$
\mathrm{H}_{\mathrm{in}}=\frac{\mathrm{A}_{\mathrm{Ra}}}{185}+\frac{\mathrm{A}_{\mathrm{Th}}}{259}+\frac{\mathrm{A}_{\mathrm{K}}}{4810} \text {. }
$$

If the maximum concentration of radium is half that of the normal acceptable limit, then $\mathrm{H}_{\text {in }}$ will be less than 1. For the safe use of a material in the construction of dwellings, $H_{\text {in }}$ must be less than unity (Beretka and Mathew, 1985). The calculated values of $\mathrm{H}_{\text {in }}$ range from 0.53 to 0.70 with an average of 0.59 , as shown in Table IV, values which are indeed less than unity. 


\subsection{Absorbed and annual effective dose rate}

The quantities commonly used for the estimation of external exposure to the population from terrestrial radionuclides are the absorbed dose rate in air and the annual effective dose rate. The external absorbed dose rate $\mathrm{D}_{\text {out }}$, in outdoor air at $1 \mathrm{~m}$ above the ground level, to the population can be calculated using the following formula (Kohshi et al., 2001; Quindos et al., 2004) from activities of terrestrial radionuclides $\left({ }^{226} \mathrm{Ra},{ }^{232} \mathrm{Th}\right.$ and $\left.{ }^{40} \mathrm{~K}\right)$ :

or

$$
\begin{gathered}
\mathrm{D}_{\text {out }}=\mathrm{A}_{\mathrm{Ei}} \times \mathrm{C}_{\mathrm{F}} \\
\mathrm{D}_{\text {out }}=0.4551 \times \mathrm{A}_{\mathrm{Ra}}+0.5835 \times \mathrm{A}_{\mathrm{Th}}+0.0429 \times \mathrm{A}_{\mathrm{K}}
\end{gathered}
$$

where $A_{E i}\left(A_{R a}, A_{T h}\right.$ and $\left.A_{K}\right)$ are the activity concentrations of ${ }^{226} \mathrm{Ra},{ }^{232} \mathrm{Th}$ and ${ }^{40} \mathrm{~K}$ in Bq. $\mathrm{kg}^{-1}$ and $\mathrm{C}_{\mathrm{F}}$ is the dose conversion factor (absorbed dose rate in air per unit activity per unit mass, is in units of $\mathrm{nGy}^{-1} \mathrm{~h}^{-1}$ per $\mathrm{Bq} \cdot \mathrm{kg}^{-1}$ ). Dose conversion factors have been extensively calculated during the last 40 years by many researchers. In the present work, the considered dose rate conversion factors for ${ }^{226} \mathrm{Ra},{ }^{232} \mathrm{Th}$ and ${ }^{40} \mathrm{~K}$ are those determined by Quindos et al. $(2004)$, where $\mathrm{C}_{\mathrm{Ra}}=$ $0.4551, \mathrm{C}_{\mathrm{Th}}=0.5835$ and $\mathrm{C}_{\mathrm{K}}=0.0429$. Considering the indoor contribution is 1.4 times higher than the outdoor dose (UNSCEAR, 2000), the indoor dose rate was calculated as well:

$$
\mathrm{D}_{\text {in }}=\mathrm{D}_{\text {out }} \times 1.4 \text {. }
$$

To estimate the annual effective dose, one has to take into account the conversion factor from the absorbed dose $\left(\mathrm{Gy} \cdot \mathrm{h}^{-1}\right)$ in air to the effective dose $\left(\mathrm{Sv} \mathrm{h}^{-1}\right)$ and the indoor occupancy factor. In the recent UNSCEAR (2000) reports, a value of $0.7 \mathrm{~Sv} . \mathrm{y}^{-1}$ was used for the conversion factor from the absorbed dose in air to the effective dose received by adults, and 0.8 for the indoor occupancy factor, implying that $80 \%$ of time is spent indoors, on average, around the world. Therefore, the annual effective doses $\left(\mathrm{mSv}_{\mathrm{y}} \mathrm{y}^{-1}\right)$ for outdoors and indoors received by adults were estimated using the following formulas:

Outdoors $\left(\mathrm{E}_{\text {out }}\right): \mathrm{D}_{\text {out }}\left(\mathrm{nGy} \cdot \mathrm{h}^{-1}\right) \times 8760 \mathrm{~h} \times 0.7 \mathrm{~Sv} \cdot \mathrm{Gy}^{-1} \times 0.2 \times 10^{-6}$

Indoors $\left(\mathrm{E}_{\text {in }}\right): \mathrm{D}_{\text {in }}\left(\mathrm{nGy} \cdot \mathrm{h}^{-1}\right) \times 8760(\mathrm{~h}) \times 0.7\left(\mathrm{~Sv} \mathrm{~Gy}^{-1}\right) \times 0.8 \times 10^{-6}$

where $\mathrm{D}_{\text {out }}\left(\mathrm{nGy} \cdot \mathrm{h}^{-1}\right)$ and $\mathrm{D}_{\text {in }}\left(\mathrm{nGy} \cdot \mathrm{h}^{-1}\right)$ are given by equations (4) and (5), $8760 \mathrm{~h}$ are the hours per year, 0.2 is the outdoor occupancy factor and 0.8 is the indoor occupancy factor. The estimated results for the absorbed dose rate and the corresponding annual effective dose rate are given in Table IV. The indoor absorbed dose rates ranged from 110.42 to $142.51 \mathrm{nGy} \cdot \mathrm{h}^{-1}$ with an average of 
TABLE IV

Hazard indices (H), absorbed dose rate (D), annual effective dose (E) and gamma activity concentration index (I) of various marble samples.

\begin{tabular}{|c|c|c|c|c|c|c|c|}
\hline \multirow[t]{2}{*}{$\begin{array}{l}\text { Sample } \\
\text { Lab. code }\end{array}$} & \multicolumn{2}{|c|}{$\begin{array}{l}\text { Hazard indices } \\
\text { (H) }\end{array}$} & \multicolumn{2}{|c|}{$\begin{array}{c}\text { Absorbed dose rate D } \\
\left(\mathrm{nGy} \cdot \mathrm{h}^{-1}\right)\end{array}$} & \multicolumn{2}{|c|}{$\begin{array}{c}\text { Annual effective dose } \\
\text { rate } \\
\mathbf{E}\left(\mathrm{mSv} \cdot \mathrm{y}^{-\mathbf{1}}\right)\end{array}$} & \multirow{2}{*}{$\begin{array}{c}\text { Gamma } \\
\text { activity } \\
\text { concentration } \\
\text { index (I) }\end{array}$} \\
\hline & $\mathbf{H}_{\mathrm{ex}}$ & $\mathbf{H}_{\text {in }}$ & $D_{\text {out }}$ & $\mathbf{D}_{\text {in }}$ & $\overline{E_{\text {out }}}$ & $\mathbf{E}_{\text {in }}$ & \\
\hline MBIT-1 & 0.47 & 0.57 & 83.73 & 117.22 & 0.10 & 0.58 & 0.67 \\
\hline MBIT-2 & 0.58 & 0.70 & 101.79 & 142.51 & 0.12 & 0.70 & 0.81 \\
\hline MBIT-3 & 0.57 & 0.67 & 100.09 & 140.13 & 0.12 & 0.69 & 0.80 \\
\hline MBIT-4 & 0.47 & 0.56 & 82.97 & 116.16 & 0.10 & 0.57 & 0.66 \\
\hline MBIT-5 & 0.45 & 0.53 & 78.87 & 110.42 & 0.10 & 0.54 & 0.63 \\
\hline MBIT-6 & 0.50 & 0.60 & 87.11 & 121.96 & 0.11 & 0.60 & 0.69 \\
\hline MBIT-7 & 0.50 & 0.60 & 87.51 & 122.51 & 0.11 & 0.60 & 0.70 \\
\hline MBIT-8 & 0.49 & 0.58 & 86.56 & 121.19 & 0.11 & 0.59 & 0.69 \\
\hline MBIND-9 & 0.48 & 0.57 & 84.08 & 117.72 & 0.10 & 0.58 & 0.67 \\
\hline MBIND-10 & 0.50 & 0.59 & 87.24 & 122.14 & 0.11 & 0.60 & 0.70 \\
\hline MBIND-11 & 0.49 & 0.58 & 85.51 & 119.72 & 0.10 & 0.59 & 0.68 \\
\hline MBIND-12 & 0.49 & 0.59 & 85.86 & 120.21 & 0.11 & 0.59 & 0.69 \\
\hline MBIND-13 & 0.45 & 0.54 & 79.44 & 111.22 & 0.10 & 0.55 & 0.63 \\
\hline MBIND-14 & 0.48 & 0.58 & 85.33 & 119.46 & 0.10 & 0.59 & 0.68 \\
\hline MBIND-15 & 0.50 & 0.59 & 87.65 & 122.72 & 0.11 & 0.60 & 0.70 \\
\hline MBPAK-16 & 0.50 & 0.63 & 88.06 & 123.28 & 0.11 & 0.60 & 0.70 \\
\hline MBPAK-17 & 0.50 & 0.60 & 87.24 & 122.13 & 0.11 & 0.60 & 0.69 \\
\hline MBGRE-18 & 0.48 & 0.57 & 84.04 & 117.66 & 0.10 & 0.58 & 0.67 \\
\hline MBPORT-19 & 0.47 & 0.56 & 82.42 & 115.39 & 0.10 & 0.57 & 0.66 \\
\hline Maximum & 0.58 & 0.70 & 101.79 & 142.51 & 0.12 & 0.70 & 0.81 \\
\hline Minimum & 0.45 & 0.53 & 78.87 & 110.42 & 0.10 & 0.54 & 0.63 \\
\hline Average & $0.49 \pm 0.03$ & $0.59 \pm 0.04$ & $86.61 \pm 5.7$ & $121.25 \pm 7.97$ & $0.11 \pm 0.02$ & $0.60 \pm 0.04$ & $0.69 \pm 0.05$ \\
\hline
\end{tabular}

121.25 nGy. $\mathrm{h}^{-1}$. The average indoor absorbed dose rate from all marble samples is 1.44 times higher than the world average (population-weighted) indoor absorbed gamma dose rate of $84 \mathrm{nGy} \cdot \mathrm{h}^{-1}$ (UNSCEAR, 2000). The indoor effective dose rates ranged from 0.54 to $0.70 \mathrm{mSv} \cdot \mathrm{y}^{-1}$ with an average of $0.60 \mathrm{mSv} \cdot \mathrm{y}^{-1}$. It is noted that the average effective dose rate is about half of the dose criterion of $1 \mathrm{mSv}^{-\mathrm{y}^{-1}}$ (EC, 1999 and ICRP, 1990). The average effective dose values are all below the limit specified for building materials in the literature. 
TABLE V

Comparison of the average hazard indices $(H)$, absorbed dose rate $(D)$, annual effective dose $(E)$ and gamma activity concentration index (I) of the marble samples in the present study with those obtained in other published data.

\begin{tabular}{|c|c|c|c|c|c|c|}
\hline \multirow[t]{2}{*}{ Country } & \multicolumn{2}{|c|}{ Hazard indices } & \multirow{2}{*}{$\begin{array}{c}\begin{array}{c}\text { Absorbed dose } \\
\text { rate D } \\
(\text { nGy.h }\end{array} \\
\text { D }\end{array}$} & \multirow{2}{*}{$\begin{array}{c}\begin{array}{c}\text { Annual } \\
\text { effective dose } \\
\text { E }\left(\mathbf{m S v} \cdot \mathbf{y}^{-1}\right)\end{array} \\
E\end{array}$} & \multirow{2}{*}{$\begin{array}{l}\text { Gamma activity } \\
\text { concentration } \\
\text { index, I }\end{array}$} & \multirow[t]{2}{*}{ References } \\
\hline & $\mathbf{H}_{\mathrm{ex}}$ & $\mathbf{H}_{\mathrm{in}}$ & & & & \\
\hline Bangladesh & 0.49 & 0.59 & $\begin{array}{l}\text { outdoor }=86.61 \\
\text { indoor }=121.25\end{array}$ & $\begin{array}{c}\text { outdoor } 0.11 \\
\text { indoor }=0.60 \\
\text { total }=0.71\end{array}$ & 0.69 & Present study \\
\hline India & 0.1193 & 0.1404 & 21.48 & 0.026 & - & Ramasamy et al. \\
\hline Pakistan & $0.03 \pm 0.02$ & $0.05 \pm 0.03$ & $6.53 \pm 3.65$ & 0.04 & - & Aslam et al. \\
\hline Pakistan & 0.19 & 0.26 & - & - & - & Iqbal et al. \\
\hline Egypt & - & - & $\begin{array}{l}2.45 \pm 0.07- \\
64.44 \pm 1.93\end{array}$ & - & - & Walley et al. \\
\hline $\begin{array}{l}\text { World } \\
\text { average }\end{array}$ & $<1$ & $<1$ & 59 & $\begin{array}{c}\text { outdoor } 0.07 \\
\text { indoor }=0.41 \\
\text { total }=0.48 \text { and } \\
1 \text { (upper limit) }\end{array}$ & $\begin{array}{c}\text { Exemption limit }= \\
0.3 \text { is met for } \mathrm{I} \leq 2 \\
\text { and upper } \operatorname{limit}= \\
1 \text { is met for } \mathrm{I} \leq 6\end{array}$ & $\begin{array}{l}\text { UNSCEAR (2000) } \\
\text { EC (1999) }\end{array}$ \\
\hline
\end{tabular}

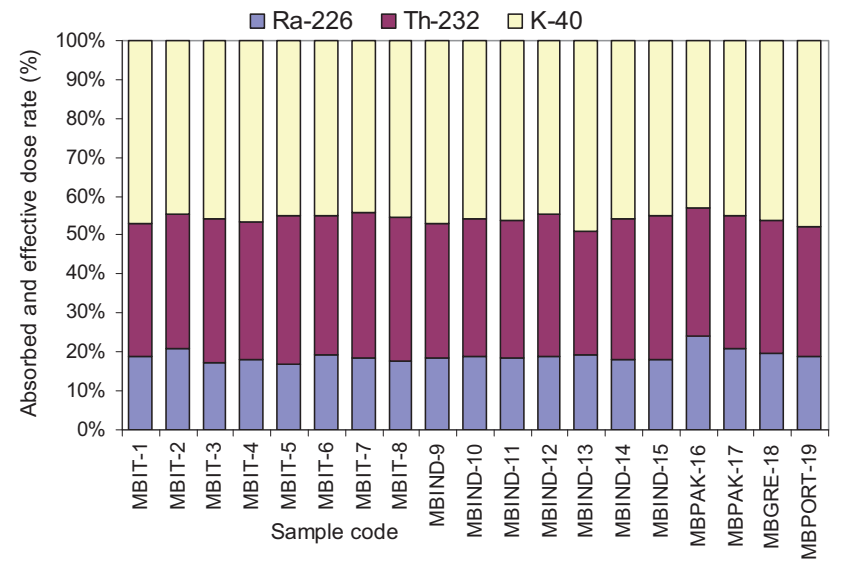

Figure 2 - Relative contributions to the absorbed dose rate and effective dose rate owing to ${ }^{226}$ Ra, ${ }^{232} \mathrm{Th}$ and ${ }^{40} \mathrm{~K}$ for the marble samples.

Figure 2 shows the relative contributions of ${ }^{226} \mathrm{Ra},{ }^{232} \mathrm{Th}$ and ${ }^{40} \mathrm{~K}$ contents to the absorbed dose rate and the effective dose rate for all marble samples. The 
average relative contribution by individual components of natural radioactivity contents to the absorbed dose rate and annual effective dose rate is $19 \%$ from ${ }^{226} \mathrm{Ra}, 35 \%$ from ${ }^{232} \mathrm{Th}$ and $46 \%$ from ${ }^{40} \mathrm{~K}$.

\subsection{Gamma activity concentration index (I)}

According to the recommendation No. 112 issued by the European Union (1999), building materials should be exempted from all restrictions concerning their radioactivity, if the excessive gamma radiation due to those materials causes an increase in the annual effective dose received by an individual by a maximum value of $0.3 \mathrm{mSv}$. Effective doses exceeding the dose criterion of $1 \mathrm{mSv}^{-1} \mathrm{y}^{-1}$ should be taken into account in terms of radiation protection. It is therefore recommended that controls should be based on a dose range of 0.3 to $1 \mathrm{mSv}^{-1} \mathrm{y}^{-1}$. In order to examine whether a building material meets these two dose criteria, the following gamma activity concentration index (I) is derived:

$$
\mathrm{I}=\frac{\mathrm{A}_{\mathrm{Ra}}}{300 \mathrm{~Bq} \cdot \mathrm{kg}^{-1}}+\frac{\mathrm{A}_{\mathrm{Th}}}{200 \mathrm{~Bq} \cdot \mathrm{kg}^{-1}}+\frac{\mathrm{A}_{\mathrm{K}}}{3000 \mathrm{~Bq} \cdot \mathrm{kg}^{-1}}
$$

where $A_{\text {Ra }}, A_{T h}$ and $A_{K}$ are activity concentrations of ${ }^{226} \mathrm{Ra},{ }^{232} \mathrm{Th}$ and ${ }^{40} \mathrm{~K}$ (in Bq. $\mathrm{kg}^{-1}$ ) in building material, respectively. For superficial (such as marble) and other building materials, the exemption dose criterion $\left(0.3 \mathrm{mSv}^{-1} \mathrm{y}^{-1}\right)$ corresponds to an activity concentration index $\mathrm{I} \leq 2$, while the dose criterion of $1 \mathrm{mSv} \cdot \mathrm{y}^{-1}$ is met for I $\leq 6$ (EC, 1999). Thus, the activity concentration index should be used only as a screening tool for identifying materials which might be of concern to be used as covering material. According to this dose criterion, materials with $\mathrm{I} \geq 6$ should be avoided, since these values correspond to dose rates higher than $1 \mathrm{mSv} \cdot \mathrm{y}^{-1}$ (EC, 1999), which is the highest value of the dose rate in air recommended for the population (UNSCEAR, 1993, 2000). According to the above equation, the values of the index I for all samples under study were $\mathrm{I}<2$, which indicated that the gamma dose contribution from the marbles under consideration was not more than $0.3 \mathrm{mSv}^{-1} \mathrm{y}^{-1}$. It should be noted that quite similar conclusions are drawn by considering the effective dose rates, which seems to be appropriate for superficial materials.

\section{Conclusion}

In this study, the activity concentrations of ${ }^{226} \mathrm{Ra},{ }^{232} \mathrm{Th}$ and ${ }^{40} \mathrm{~K}$, the radium equivalent activity, the external and internal hazard indices, the gamma activity concentration index, the absorbed gamma dose rate in indoor air, and the corresponding annual effective dose were determined to assess the radiological hazards from different varieties of marbles used as covering materials for building 
construction. Based on the assessment of potential radiological hazards as inferred from the calculations it can be concluded that the radium equivalent activity, the external and internal hazard indices, the indoor absorbed dose rate, the annual effective dose limit and the activity concentration index show that the investigated samples are within the recommended safety limit and do not pose any significant source of radiation hazard. Therefore, the use of these materials in the construction of dwellings is considered to be safe for inhabitants.

Acknowledgements. This study was carried out in the Health Physics and Radioactive Waste Management Unit (HPRWMU), Atomic Energy Research Establishment (AERE), Savar, Dhaka. The authors wish to thank the Director, INST and Head, HPRWMU, AERE and BUET authority for their kind support during this study.

\section{REFERENCES}

Amrani D., Tahtat M. (2001) Natural radioactivity in Algerian building materials, Appl. Radiat. Isotopes 54, 687-689.

Aslam M., Orfi S.D., Khan K., Jabbar A. (2002) Radiological significance of Pakistani marble used for construction of dwellings, J. Radioanal. Nucl. Chem. 253 (3), 483-487.

Beretka J., Mathew P.J. (1985) Natural radioactivity of australian building materials, industrial waste and by-products, Health Phys. 48, 87-95.

EC (European Commission) (1999) Radiological protection principles concerning the natural radioactivity of building materials. Radiation protection Vol. 112. Directorate General Environment, Nuclear Safety and Civil Protection.

ICRP (International Commission on Radiological Protection) (1990) Recommendations of the International Commission on Radiological Protection. Publication 60, Ann. ICRP 21 (1-3).

Iqbal M., Tufail M., Mirza S.M. (2000) Measurement of natural radioactivity in marble found in Pakistan using a NaI (Tl) gamma-ray spectrometer, J. Environ. Radioact. 51, 255-265.

Khan K., Khan H.M. (2001) Natural gamma-emitting radionuclides in Pakistani portland cement, Appl. Radiat. Isotopes 54, 861-865.

Khan K., Khan H.M., Tufail M., Ahmad N. (1998) Radiometric analysis of Hazara phosphate rock and fertilizers, J. Environ. Radioact. 38, 77-83.

Kohshi C., Takao I., Hideo S. (2001) Terrestrial gamma radiation in Koshi prefecture, Japan. Health Sci. 47 (4), 362-372.

Krisiuk E.M., Tarasov S.I., Shamov V.P., Shalak N.I., Lisa Chenko E.P., Gomelsky L.G. (1971) A Study on radioactivity in building materials. Leningrad: Research Institute for Radiation Hygiene.

Kumar A., Kumar M., Singh B., Singh S. (2003) Natural activities of ${ }^{238} \mathrm{U},{ }^{232} \mathrm{Th}$ and ${ }^{40} \mathrm{~K}$ in some Indian building materials, Radiat. Meas. 36, 465-469.

Kumar V., Ramachandran T.V., Prasad R. (1999) Natural radioactivity of Indian building materials and by-products. Appl. Radiat. Isotopes 51, 93-96.

Malanca A., Pessina V., Dallara G. (1993) Radionuclide content of building materials and gamma-ray dose rates in dwellings of Rio Grande Do Norte, Brazil, Radiat. Prot. Dosim. 48, 199-203.

Mustonen R. (1984) Natural radioactivity and radon exhalation rate from Finish building materials, Health Phys. 46, 1195-1203. 
Nageswara Rao M.V. (1989) Natural radioactivity levels in some environmental materials from Rajasthan, Bull. Radiat. Prot. 12, 36-41.

NEA/OECD (1979) Nuclear Energy Agency. Exposure to radiation from natural radioactivity in building materials. Report by NEA Group of Experts (OECD, Nuclear Agency, Paris, France).

Nour Khalifa Ahmed (2005) Measurement of natural radioactivity in building materials in Qena city, Upper Egypt, J. Environ. Radioact. 1, 91-99.

Quindos L.S., Fernańdez P.L., Ródenas C., Gómez-Arozamena J., Arteche J. (2004) Conversion factors for external gamma dose derived from natural radionuclides in soils, J. Environ. Radioact. 71, 139-145.

Ramasamy V., Ponnusamy V., Hemalatha J., Meenakshisundaram V., Gajendiran V. (2005) Evaluation of natural radioactivity and radiological hazards caused by different marbles of India, Indian J. Pure Appl. Phys. 43, 815-820.

Rizzo S., Brai M., Basile S., Bellia S., Hauser S. (2001) Gamma activity and geochemical features of building materials: estimation of gamma dose rate and indoor radon levels in Sicily, Appl. Radiat. Isotopes 55, 259-265.

Steger F., Kunsch B., Buchner I. (1992) Radioactivity in building materials (a Standard in Austria to limit natural radioactivity in building materials), Radiat. Prot. Dosim. 45 (1/4), 721-722.

Stranden E. (1976) Some aspects of radioactivity of building materials, Phys. 8, 167-177.

Turhan Ş., Baykan U.N., Şen K. (2008) Measurement of the natural radioactivity in building materials used in Ankara and assessment of external doses, J. Radiol. Prot. 28, 83-91.

UNSCEAR (2000) Report to general assembly. Annex B: exposure from natural radiation sources.

UNSCEAR (United Nations Scientific Committee on the Effects of Atomic Radiation) (1993) Sources, effects and risks of ionizing radiation.

UNSCEAR (1982) Ionizing radiation sources and biological effects. United Nations Scientific Committee on the Effects of Atomic Radiation.

Walley El-Dine N., El-Shershaby A., Ahmed F., Abdel-Haleem A.S. (2001) Measurement of radioactivity and radon exhalation rate in different kinds of marbles and granites, Appl. Radiat. Isotopes 55, 853-860. 